\title{
Two new species of deep-water Calcigorgia gorgonians (Anthozoa: Octocorallia) from the Kurile Islands, Sea of Okhotsk, with a review of distinctive characters of the known species of the genus
}

\author{
Tatiana N. DAUTOVA ${ }^{1,2}$ \\ ${ }^{1}$ A.V. Zhirmunsky Institute of Marine Biology, National Scientific Center of Marine Biology, \\ Far Eastern Branch of Russian Academy of Sciences, Vladivostok, Russia. \\ ${ }^{2}$ Far Eastern Federal University, Vladivostok, Russia. \\ Email: tndaut@mail.ru
}

urn:1sid:zoobank.org:author:15E9D523-DDB9-4D7A-B837-7EC3937D044D

\begin{abstract}
This paper provides descriptions of Calcigorgia gorgonians collected from the Sea of Okhotsk and shores of the Kurile Islands between 3 Aug. 1984 and 20 Aug. 1987. New species described are the deep-water gorgonians Calcigorgia matua sp. nov. and C. simushiri sp. nov., belonging to the temperate fauna of the North Pacific hemisphere. Specimens belonging to all species of the genus were examined and the distinctive characters for each one are provided and summarized in a table. A modified diagnosis of the genus is proposed. The finding of a previously undescribed species emphasizes the need of further surveys, particularly in shelf and deeper waters, in order to improve our knowledge of this neglected fauna in Far East seas.
\end{abstract}

Keywords. Calcigorgia matua sp. nov., Calcigorgia simushiri sp. nov., Octocorallia, taxonomy, deepwater corals, Kurile Islands.

Dautova T.N. 2018. Two new species of deep-water Calcigorgia gorgonians (Anthozoa: Octocorallia) from the Kurile Islands, Sea of Okhotsk, with a review of distinctive characters of the known species of the genus. European Journal of Taxonomy 408: 1-22. https://doi.org/10.5852/ejt.2018.408

\section{Introduction}

The Octocorallia Haeckel, 1866 of the Sea of Okhotsk are very poorly known. Broch (1935) examined the material collected by Prof. K.M. Deryugin at depths between 72 and 515 m (Okhotsk Sea) and between 600 and $700 \mathrm{~m}$ (Tatarian Gulf). The following gorgonian species were reported: Euplexaura abietina Kükenthal, 1908, E. arbuscula Broch, 1935, Plumarella longispina Kinoshita, 1908, Calyptrophora ijimai Kinoshita, 1908, and Primnoa resedaeformis (Gunnerus, 1763), known now as P. pacifica Kinoshita, 1907 (see Cairns \& Bayer 2005). Broch (1935) also described the new gorgonian genus - Calcigorgia Broch, 1935 using material collected at a depth of 150-165 m near the north of Sakhalin Island. Only the type species Calcigorgia spiculifera Broch, 1935 was known until another member of the genus - Calcigorgia japonica Dautova, 2007 - was described from the central part of the Sea of Japan from material collected at a depth of 832-736 m (Dautova 2007). However, examination 
of material collected by Institutions of the Russian Academy of Sciences in a series of expeditions of the second half of $20^{\text {th }}$ century provided evidence that this list of deep-water gorgonians inhabiting the Sea of Okhotsk is by no means complete. The present paper presents new data about the species composition of Calcigorgia Broch, 1935 gorgonians, including description of the new species Calcigorgia matua sp. nov. and C. simushiri sp. nov. The taxonomic importance of some characters is discussed.

\section{Material and methods}

The samples were collected during field expeditions of the Pacific Fisheries Research Center PFRC, with participation of the Zoological Institute (ZIN RAS) of the Russian Academy of Sciences (1985, RV "Odyssey"; 1987, RV "Tikhookeansky"), by trawling and dredging. The specimens were fixed in $70 \%$ ethanol and are registered in MIMB (Museum of the Institute of Marine Biology, National Scientific Center of Marine Biology FEB RAS, Vladivostok, Russia) and in the Zoological Institute RAS (St.-Petersburg, Russia), abbreviated MIMB and ZIN RAS, respectively, in the following text. The tissue samples of different colony parts (tentacles, polyp body wall, and coenenchyme) were examined separately through dissolving of the organic matter in sodium hypochlorite and observing under an optical microscope $(200 \times)$. The sclerites were washed from hypochlorite with distilled water and ethanol (70\%), air-dried, mounted for the SEM on carbon double adhesive tape, and coated. Detailed images of the sclerites were obtained with SEM using a Zeiss Evo 40 and optimum magnification for each sclerite type. The sclerite types are distinguished and named in accordance with Bayer et al. (1983).

\section{Results}

Phylum Cnidaria Verrill, 1865

Class Anthozoa Ehrenberg, 1834

Subclass Octocorallia Haeckel, 1866

Order Alcyonacea Lamouroux, 1812

Suborder Holaxonia Studer, 1887

Family Acanthogorgiidae Gray, 1859

Genus Calcigorgia Broch, 1935

\section{Diagnosis}

Acanthogorgiid gorgonians whose sclerites are not individually conspicuous and not regularly arranged in the polyp. Sclerites are spindles, capstans, ovals, and clubs with warty and leafy heads.

\section{Remarks}

The diagnosis given above combines those provided by Broch (1935) and Bayer (1981), and adds the case when clubs with leafy heads are present in the sclerites' arrangement, as will be shown below for the Calcigorgia matua sp. nov.

Gorgonians of the genus Calcigorgia are distributed from Alaska and the Aleutian Islands to Kurile and Sakhalin Island to the north and to the northwestern Sea of Japan to the south, depth range is to a depth of 900 m (Broch 1935; Heifetz 2002; Heifetz et al. 2005; Dautova 2007). 


\section{Calcigorgia matua sp. nov. \\ urn:lsid:zoobank.org:act:DB4011CF-7B0E-4022-B39F-4E7A30B58E26}

Figs 1-5; Table 1

\section{Diagnosis}

Polyps remote of each other, arranged irregularly on the surface of the branch, in alcohol-preserved material $1-5 \mathrm{~mm}$ high and $2.5 \mathrm{~mm}$ wide. Body walls of polyps have a smooth surface; the lower part of the polyp is slightly widened. In the tentacles and the body wall, and in the coenenchyme, sclerites are unordered.

Polyp tentacles contain: (1) flattened sclerites; (2) clubs, up to $0.14 \mathrm{~mm}$ long, with a warty handle and leafy processes on the head; (3) clubs, up to $0.15 \mathrm{~mm}$ long, with warty heads, and (4) warty spindles, up to $0.18 \mathrm{~mm}$ long. The polyp body walls contain: (1) clubs, up to $0.14 \mathrm{~mm}$ long, with a warty handle and leafy processes on the head; (2) clubs, up to $0.15 \mathrm{~mm}$ long, with warty heads; (3) capstans and 8-radiates, up to $0.17 \mathrm{~mm}$ long; and (4) warty spindles, up to $0.18 \mathrm{~mm}$ long. The outer layer of coenenchyme is densely filled with capstans (8-radiates), up to $0.15 \mathrm{~mm}$ long, and may contain well calcified ovals of same size. Warty spindles up to $0.15 \mathrm{~mm}$ long and leafy clubs, up to $0.9 \mathrm{~mm}$ long, are also present here along with warty clubs up to $0.15 \mathrm{~mm}$ long.

\section{Etymology}

The specific epithet is after Matua Island (Kurile Islands, Sea of Okhotsk), nearest to the locality where the holotype was found.

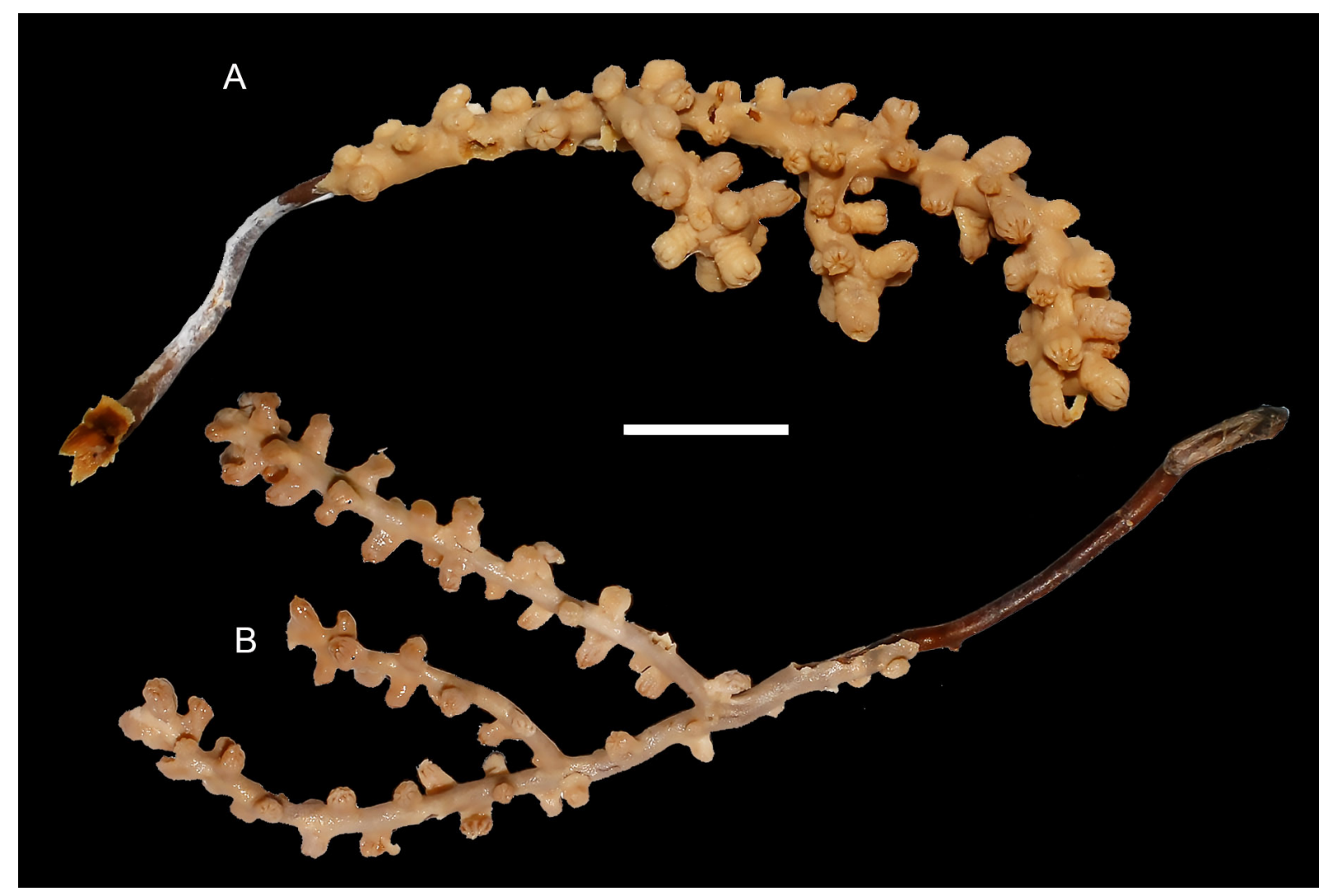

Fig. 1. Calcigorgia matua sp. nov. A. Holotype (MIMB 20722), Kurile Islands, Sea of Okhotsk. B. Paratype (MIMB 20724), Kurile Islands, Sea of Okhotsk. Scale bar: $10 \mathrm{~mm}$. 


\section{Type material}

\section{Holotype}

KURILE ISLANDS: $65 \times 25 \mathrm{~mm}$, sample 901, Expedition of PFRC and ZIN RAS on RV "Tikhoo-

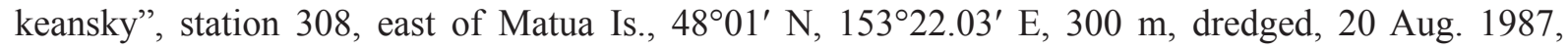
S. Grebelnyi leg. (MIMB 20722).

\section{Paratype}

KURILE ISLANDS: 1 specimen, $75 \times 27 \mathrm{~mm}$, Cruise No 34 of PFRC and ZIN RAS on RV “Odyssey",

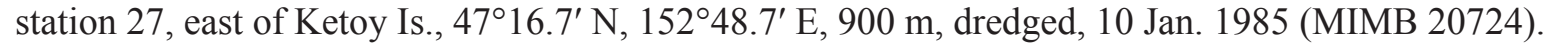

\section{Additional material}

KURILE ISLANDS: 2 specimens, near Lovushki Rocks, cruise No 33 of ZIN RAS on RV “Odyssey", 48 02' N, 154²4' E, 400 m, dredged, 3 Aug. 1984 (ZIN RAS 11807, ZIN RAS 11808); 1 specimen, same collecting data as previous, but 8 Aug. 1984 (ZIN RAS 11809).

\section{Comparative material examined}

Calcigorgia spiculifera Broch, 1935

KURILE ISLANDS: 1 specimen, $70 \times 47 \mathrm{~mm}$, expedition of PFRC and RAS on RV "Akademik

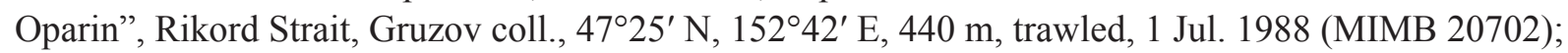
1 specimen, $62 \times 40 \mathrm{~mm}$ expedition of PFRC and RAS on RV “Tikhookeansky", Urup Isl., 46 ${ }^{\circ} 19.7^{\prime} \mathrm{N}$, $150^{\circ} 42^{\prime} \mathrm{E}, 100 \mathrm{~m}$, trawled, 1987, V. Lukin leg. (MIMB 20693).

Calcigorgia japonica Dautova, 2007

SEA OF JAPAN: 1 specimen, $39^{\circ} 35^{\prime} \mathrm{N}, 135^{\circ} 01^{\prime}$ E, 832-736 m, 8 Aug. 1933, K.M. Deryugin leg. (ZIN RAS 1/10706).

\section{Description}

Scantily branched delicate colonies. Side branches placed irregularly. Holotype alcohol-preserved colony of $65 \mathrm{~mm}$ high and $25 \mathrm{~mm}$ wide (Fig. 1A). Paratype $75 \mathrm{~mm}$ high and $27 \mathrm{~mm}$ wide (Fig. 1B). Polyps up to $5 \mathrm{~mm}$ high and $2.2 \mathrm{~mm}$ wide, disposed irregularly at distances of $2-10 \mathrm{~mm}$ from each other. Tentacles folded over polyp and partly retracted to the inside. Polyp body is smooth and slightly widening downward. No polyps entirely retracted into coenenchyme.

Coenenchyme is a $0.3 \mathrm{~mm}$ thick and consists of two layers, a $0.15 \mathrm{~mm}$ thick outer layer, with smooth surface and a very thin, semi-transparent inner layer. Axis made of concentric layers. Axial canal in this specimen very narrow and, therefore, hardly visible. Sclerites unordered in tentacles, polyp body wall and coenenchyme.

Tentacles contain flattened elongated bodies, clubs and spindles. Flattened bodies of irregular shape, mainly $0.7-0.9 \mathrm{~mm}$ long, covered by sparse tubercles (Fig. 2A). Clubs mainly $0.09-0.12 \mathrm{~mm}$ long, sometimes up to $0.14 \mathrm{~mm}$, with a plump or elongated head, consisting of several leafy processes (Fig. 2B). Short handle straight or slightly curved, pointed or blunt, and ornamented with small warts. Some longer clubs, up to $0.18 \mathrm{~mm}$, with staggered leafy processes on head (Fig. 2C) transitional to warty. Warty clubs mainly up to $0.12-0.15 \mathrm{~mm}$ long; their handles with well-developed warts tending to be girdled (Fig. 2D). Small spindles straight, usually up to $0.1-0.12 \mathrm{~mm}$ long. Some of these spindles up to $0.18 \mathrm{~mm}$ long, ornamented with tall hillocks tending to be girdled (Fig. 2E). 
Numerous clubs in body wall of polyps, mainly $0.11-0.14 \mathrm{~mm}$ long, with a plump head consisting of leafy processes (Fig. 3A). Handles of clubs mostly thick, with a girdle of well-developed warts. Longer clubs, up to $0.15 \mathrm{~mm}$, with staggered leafy processes on head (Fig. 3B) are transitional to warty, mostly 0.12-0.15 mm long (Fig. 3C). Warty club-like spindles, up to $0.15 \mathrm{~mm}$ long, with well-developed warts arranged into 4-5 girdles (Fig. 3D). Warty clubs also coincide with capstans, mostly $0.15-0.17 \mathrm{~mm}$ long, with girdled warts and plump terminal tufts (Fig. 3E), and ovals bearing some unordered processes (Fig. 3F). Spindles, mostly $0.15-0.17 \mathrm{~mm}$ long, also occur. These spindles have 4 girdles of more or less developed warts and plump terminal warts (Fig. 3G). Spindles and ovals common here.

External layer of coenenchyme comprises leafy clubs, mostly $0.08-0.09 \mathrm{~mm}$ long, with short blunt handle (Fig. 4A) and sparse warty clubs, mostly $0.13-0.15 \mathrm{~mm}$. These clubs with well developed heads and blunt warty handles (Fig. 4B). Warty spindles, mostly $0.13 \mathrm{~mm}$ long, also occur here (Fig. 4C). Capstans, up to $0.13-0.15 \mathrm{~mm}$, numerous; these are well-calcified 8-radiate sclerites with two girdles of warts and plump terminal processes (Fig. 4D). Some capstans, up to $0.10-0.13 \mathrm{~mm}$ long, less calcified, but with well-formed and girdled warts (Fig. 4E). Well-calcified capstans with very developed warts are transitional to the ovals, up to $0.15 \mathrm{~mm}$ long (Fig. 4F).

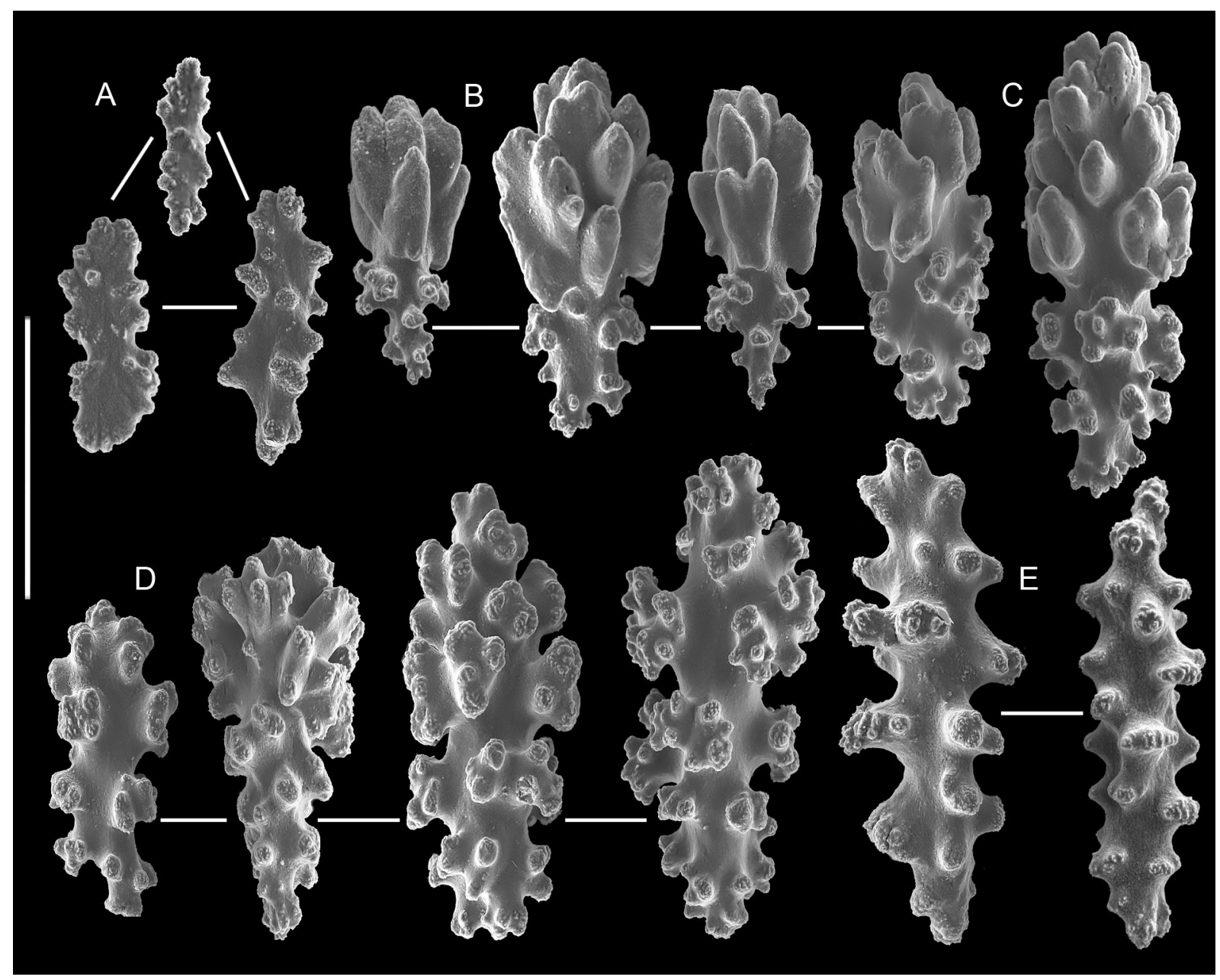

Fig. 2. Calcigorgia matua sp. nov., holotype (MIMB 20722), sclerites from the tentacles of polyp. A. Flattened bodies. B. Clubs with a head consisting of leafy processes. C. Longer clubs with staggered leafy processes on a head. D. Warty clubs. E. Spindles. Scale bar: $0.1 \mathrm{~mm}$. 


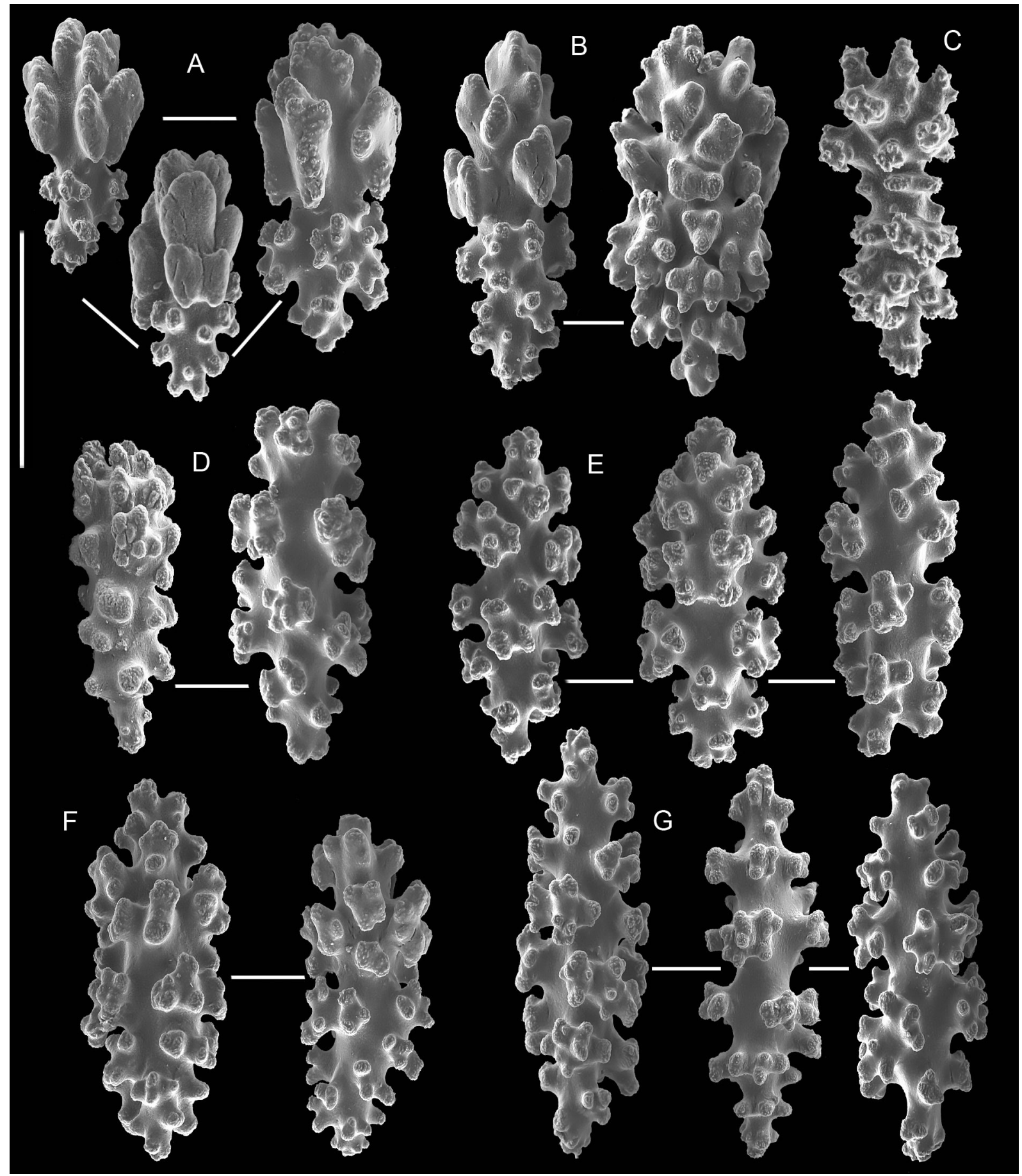

Fig. 3. Calcigorgia matua sp. nov., holotype (MIMB 20722), sclerites from the polyp body wall. A. Clubs with a head consisting of leafy processes. B. Longer clubs with staggered leafy processes on a head. C. Warty clubs. D. Club-like spindles ornamented with well-developed warts. E. Capstans ornamented with girdled warts. F. Ovals. G. Spindles. Scale bar: $0.1 \mathrm{~mm}$. 


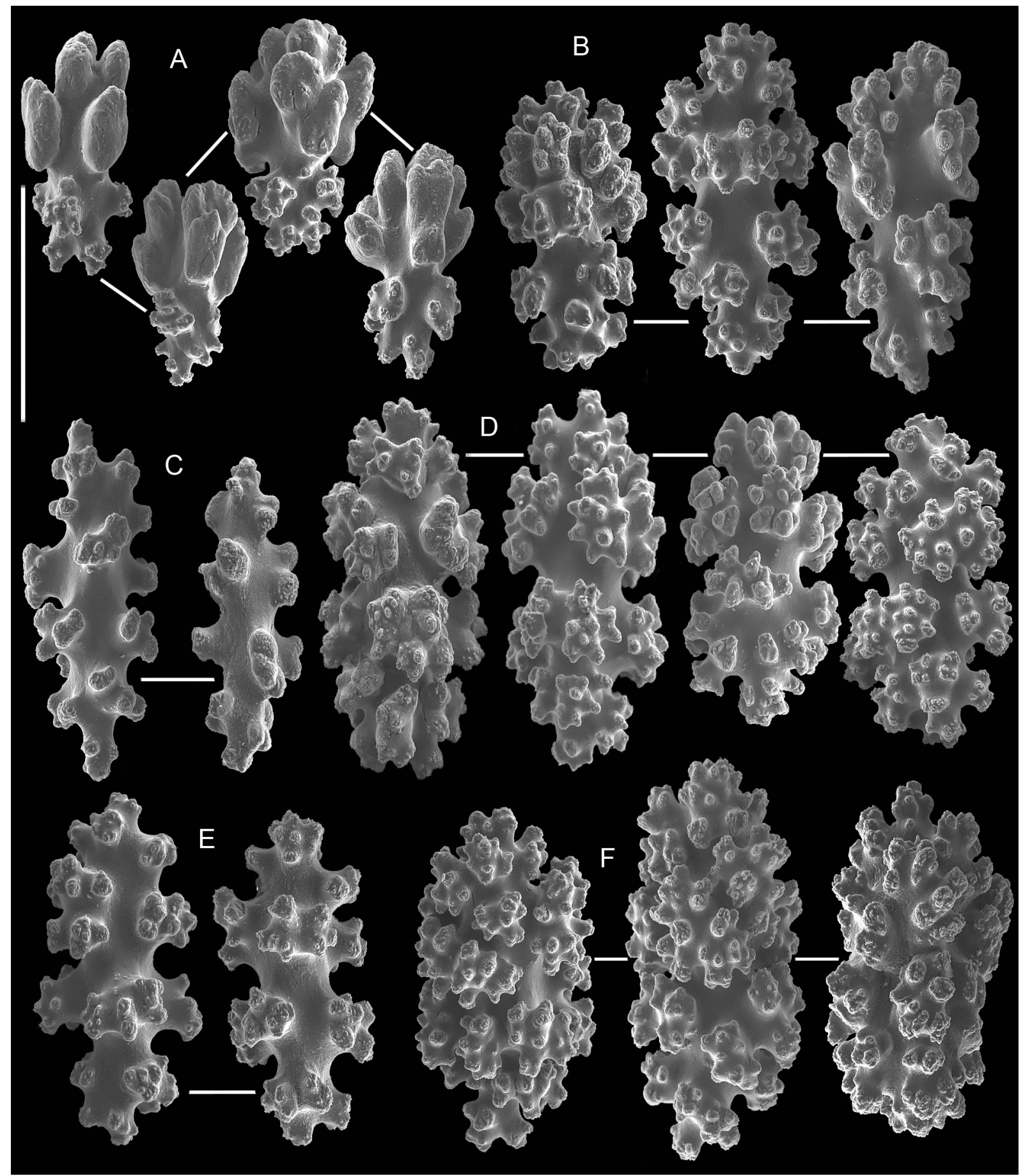

Fig. 4. Calcigorgia matua sp. nov., holotype (MIMB 20722), sclerites from the coenenchyme. A. Clubs with a head consisting of leafy processes. B. Warty clubs. C. Spindles. D. Well calcified capstans. E. Capstans with less developed processes. F. Ovals. Scale bar: $0.1 \mathrm{~mm}$. 


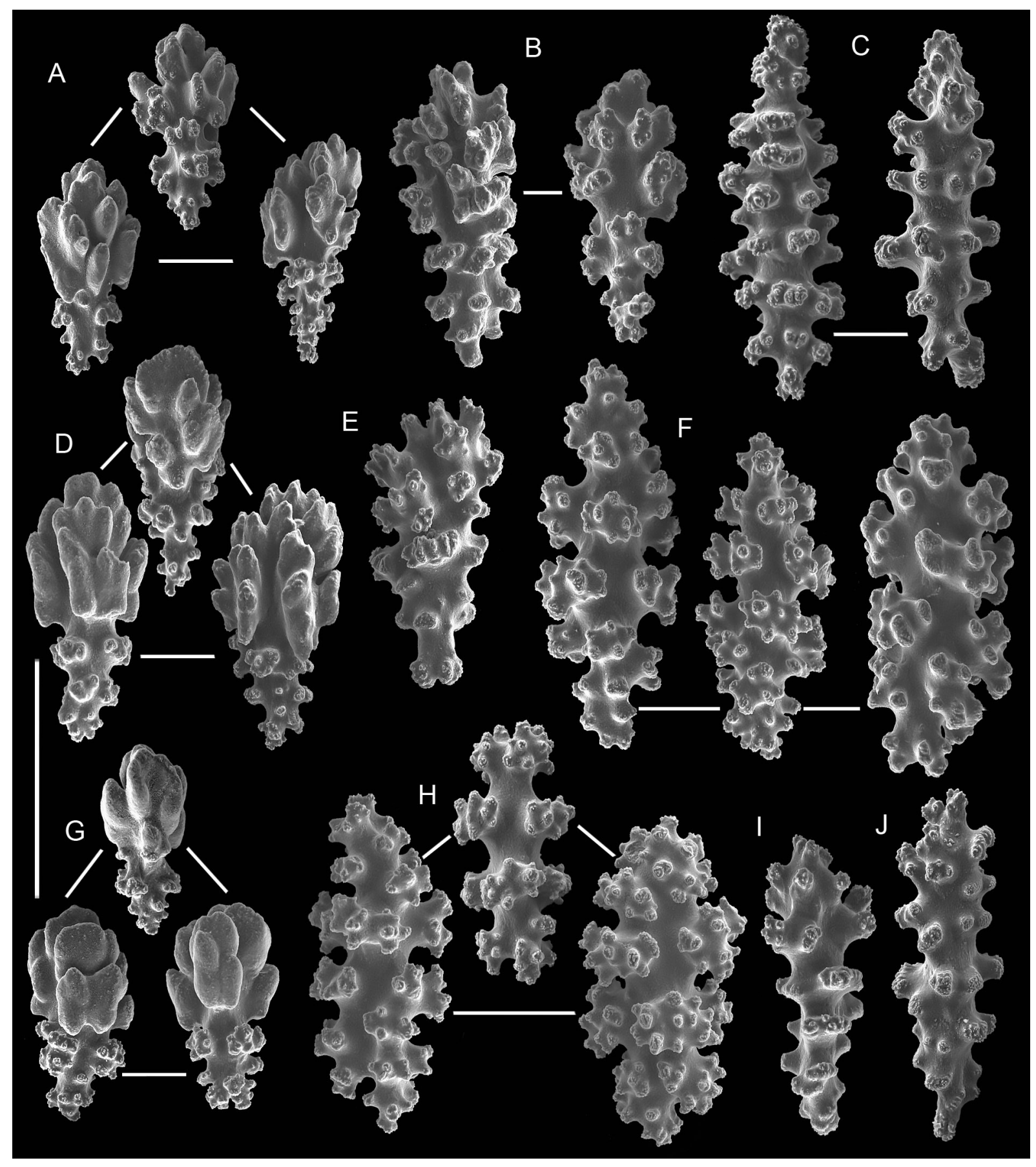

Fig. 5. Calcigorgia matua sp. nov., paratype (MIMB 20724), sclerites. A. Leafy clubs of the tentacles. B. Warty clubs from the tentacles. C. Spindles from the tentacles. D. Leafy clubs from the polyp body wall. E. Warty club from polyp body wall. F. Capstans and 8-radiate bodies of the polyp body wall. G. Leafy clubs from the coenenchyme. H. Capstans and 8-radiate bodies from the coenenchyme. I. Warty club from the coenenchyme. J. Spindle from coenenchyme. Scale bar: $0.1 \mathrm{~mm}$. 
Internal layer of coenenchyme contains weakly calcified capstans, up to $0.13 \mathrm{~mm}$ long, of same shape as those in the outer layer (Fig. 4E).

\section{Paratype and variations}

Paratype MIMB 20724 colony shape and size similar to holotype (Fig. 1B). Sclerites composition (Fig. 5) coincides with that in holotype (Figs 2-4). The only difference is less calcification of sclerites in coenenchyme of paratype - it contains no ovals, but capstans and 8-radiate sclerites with two girdles of warts and plump terminal processes are present here (Fig. 5H). Paratype's sclerites slightly smaller leafy clubs in polyp and coenenchyme up to $0.1 \mathrm{~mm}$ long (Fig. 5A, D, G) vs up to $0.14 \mathrm{~mm}$ in holotype (Figs 2B-C, 3A-B). Capstans in polyp of paratype up to $0.15 \mathrm{~mm}$ long (Fig. $5 \mathrm{~F}$ ) vs up to $0.18 \mathrm{~mm}$ in holotype (Fig. 3E).

\section{Colour}

In alcohol preserved material: polyps and coenenchyme creamy; colony axis black or deeply brown, sclerites colourless.

\section{Distribution}

This species is known for certain from the Kurile Islands, Sea of Okhotsk, Northwestern Pacific. Depth range is from $300 \mathrm{~m}$ to $900 \mathrm{~m}$.

\section{Remarks}

This species should be identified as a member of the family Acanthogorgiidae, as it agrees well enough with the distinctive characters of the family: polyps are not divided into an anthocodia and anthostele; tentacles, when retracted, are folded above oral disk (Bayer 1981; Fabricius \& Alderslade 2001). Within the family Acanthogorgiidae, the examined specimen should be referred to as belonging to the genus Calcigorgia Broch, 1935, as its distinctive characters agree with those of the latter: sclerites are small spindles, capstans and clubs that are irregularly distributed in the polyp (Broch 1935; Bayer 1981).

The most obvious distinctive characters of C. matua sp. nov., differing from characters of other known members of the genus, are the shape of polyps (with a slender wider part, no folded peduncle in fixed specimens) and the presence of two different types of clubs among the sclerites. One of these types, the clubs with leaf-like processes on their heads and warty handle, has been described in neither C. japonica nor C. spiculifera.

All three species of Calcigorgia differ from each other in the composition of polyp sclerites (see Table 1). While the shape of warty clubs of the polyp and coenenchyme is the same in C. matua sp. nov., $C$. japonica and C. spiculifera, the size of these sclerites differs significantly (see Table 1 ). Thus, the morphology of polyps and composition and size of sclerites in polyp and coenenchyme are rather clearly different in the three species. This did not allow us to refer the examined specimen to one of the already known species of the genus Calcigorgia Broch, 1935.

Calcigorgia simushiri sp. nov. urn:1sid:zoobank.org:act:2F87071C-526E-4770-AE7D-ABC45DEC0828

Figs 6-13; Table 1

\section{Diagnosis}

Polyps remote from each other, arranged irregularly on the surface of the branch, in alcohol preserved material 5-10 mm high and $4 \mathrm{~mm}$ wide. Polyp body wall cylindrical in shape and with smooth surface. Sclerites are unordered in the tentacles, the body wall and the coenenchyme. 
Table 1. Distinctive characters of species in the genus Calcigorgia Broch, 1935. The greatest length for the different types of sclerites is provided in parentheses.

\begin{tabular}{|c|c|c|c|c|}
\hline \multirow[t]{2}{*}{ Species } & \multirow{2}{*}{$\begin{array}{l}\text { Shape of polyp } \\
\text { after fixation }\end{array}$} & \multicolumn{3}{|c|}{ Sclerites } \\
\hline & & tentacles & polyp body wall & coenenchyme \\
\hline $\begin{array}{l}\text { C. spiculifera } \\
\text { Broch, } 1935\end{array}$ & $\begin{array}{l}\text { Polyp body } \\
\text { in the shape of } \\
\text { a cylindrical } \\
\text { "cap" up to } 5 \mathrm{~mm} \\
\text { tall and } 3 \mathrm{~mm} \\
\text { wide. Tentacles } \\
\text { partly retracted to } \\
\text { the inside }\end{array}$ & $\begin{array}{l}\text { (1) flattened bodies } \\
(0.12 \mathrm{~mm}) \text {; } \\
(2) \text { warty clubs }(0.25 \\
\mathrm{mm}) \text { with asym- } \\
\text { metrically developed } \\
\text { processes on the heads } \\
\text { and short handles; } \\
\text { (3) straight spindles } \\
\text { and club-like spindles } \\
(0.25 \mathrm{~mm}) \text { with tall and } \\
\text { asymmetrically } \\
\text { developed processes }\end{array}$ & \begin{tabular}{|l}
$(1)$ warty clubs \\
$(0.22 \mathrm{~mm})$ \\
with more or less asym- \\
metrically developed \\
processes on the heads \\
and short handles; \\
$(2)$ capstans $(0.22 \mathrm{~mm})$; \\
(3) ovals $(0.22 \mathrm{~mm})$; \\
(4) straight spindles \\
and club-like spindles \\
$(0.25 \mathrm{~mm})$ with tall \\
processes
\end{tabular} & $\begin{array}{l}\text { (1) warty clubs } \\
(0.17 \mathrm{~mm}) \text { with short } \\
\text { handle; } \\
(2) \text { capstans }(0.2 \mathrm{~mm}) \text {; } \\
\text { (3) ovals }(0.2 \mathrm{~mm}) \text {; } \\
\text { (4) straight spindles and } \\
\text { club-like warty spindles } \\
(0.25 \mathrm{~mm})\end{array}$ \\
\hline $\begin{array}{l}\text { C. japonica } \\
\text { Dautova, } 2007\end{array}$ & $\begin{array}{l}\text { Polyps, up to } \\
5 \mathrm{~mm} \text { tall and } \\
2.2 \mathrm{~mm} \text { wide, } \\
\text { have a thin } \\
\text { folded peduncle } \\
\text { in the lower } \\
\text { part. Tentacles } \\
\text { retracted }\end{array}$ & $\begin{array}{l}\text { (1) straight and slightly } \\
\text { curved clubs }(0.26 \\
\text { mm) with long pointed } \\
\text { handles and asymmetri- } \\
\text { cally developed } \\
\text { ornamentation on nar- } \\
\text { row heads; } \\
\text { (2) fusiform straight } \\
\text { and slightly curved } \\
\text { spindles and club-like } \\
\text { spindles }(0.35 \mathrm{~mm}) \\
\text { bearing sparse spinules }\end{array}$ & $\begin{array}{l}\text { (1) warty clubs } \\
(0.15 \mathrm{~mm}) \text { with short } \\
\text { handles; } \\
(2) \text { flattened pointed } \\
\text { spindles }(0.16 \mathrm{~mm})\end{array}$ & $\begin{array}{l}\text { (1) warty clubs } \\
(0.13 \mathrm{~mm}) \text { with short } \\
\text { handles; } \\
\text { (2) straight spindles } \\
(0.26 \mathrm{~mm}) \text { with com- } \\
\text { plex side processes, } \\
\text { sometimes with 2- or } \\
\text { 3-furcated ends; } \\
\text { (3) irregular sclerites } \\
\text { and crosses }\end{array}$ \\
\hline $\begin{array}{l}\text { C. matua } \\
\text { sp. nov. }\end{array}$ & $\begin{array}{l}\text { Polyps, up to } 5 \\
\text { mm tall and } 2.5 \\
\text { mm wide, smooth } \\
\text { body wall slightly } \\
\text { widening down- } \\
\text { ward; tentacles } \\
\text { folded over the } \\
\text { polyp and partly } \\
\text { retracted to the } \\
\text { inside }\end{array}$ & $\begin{array}{l}\text { (1) flattened elon- } \\
\text { gated bodies }(0.9 \mathrm{~mm}) \text {; } \\
\text { (2) clubs }(0.18 \mathrm{~mm}) \\
\text { with leafy heads and } \\
\text { blunt warty handles; } \\
\text { (3) warty clubs }(0.15 \\
\text { mm) with blunt } \\
\text { handles; } \\
\text { (4) straight spindles } \\
(0.18 \mathrm{~mm}) \text { covered by } \\
\text { tall hillocks tending to } \\
\text { be girdled }\end{array}$ & $\begin{array}{l}\text { (1) clubs }(0.15 \mathrm{~mm}) \\
\text { with leafy heads and } \\
\text { blunt warty handles; } \\
\text { (2) warty clubs } \\
(0.15 \mathrm{~mm}) \text {; } \\
\text { (3) spindles and club- } \\
\text { like spindles }(0.17 \mathrm{~mm}) \\
\text { bearing girdled warts; } \\
\text { (4) capstans }(0.17 \mathrm{~mm}) \text {; } \\
\text { (5) ovals }(0.17 \mathrm{~mm})\end{array}$ & $\begin{array}{l}\text { (1) clubs }(0.09 \mathrm{~mm}) \\
\text { with leafy heads and } \\
\text { short warty handles; } \\
\text { (2) warty clubs } \\
(0.15 \mathrm{~mm}) \text { with blunt } \\
\text { handles; } \\
(3) \text { warty spindles } \\
(0.13 \mathrm{~mm}) \text {; } \\
\text { (4) capstans }(0.15 \mathrm{~mm}) \text {; } \\
\text { (5) ovals }(0.15 \mathrm{~mm})\end{array}$ \\
\hline $\begin{array}{l}\text { C. simushiri } \\
\text { sp. nov. }\end{array}$ & $\begin{array}{l}\text { Polyps, up to } \\
10 \text { mm tall and } \\
4 \text { mm wide; } \\
\text { body cylindri- } \\
\text { cal in shape and } \\
\text { smooth; tentacles } \\
\text { folded over the } \\
\text { polyp and partly } \\
\text { retracted to the } \\
\text { inside }\end{array}$ & \begin{tabular}{|l} 
(1) warty clubs \\
$(0.35 \mathrm{~mm}) ;$ \\
$(2)$ club-like spindles \\
$(0.3 \mathrm{~mm})$ and spindles \\
$(0.4 \mathrm{~mm})$
\end{tabular} & $\begin{array}{l}\text { (1) warty clubs } \\
(0.28 \mathrm{~mm}) \text {; } \\
(2) \text { club-like spindles } \\
\text { and spindles }(0.4 \mathrm{~mm}) \text {; } \\
(3) \text { capstans and ovals } \\
(0.15 \mathrm{~mm})\end{array}$ & $\begin{array}{l}\text { (1) capstans }(0.15 \mathrm{~mm}) \text {; } \\
\text { (2) ovals }(0.15 \mathrm{~mm}) \\
\text { (3) few spindles } \\
(0.19 \mathrm{~mm})\end{array}$ \\
\hline
\end{tabular}


Polyp tentacles contain: (1) warty clubs, up to $0.28 \mathrm{~mm}$ long; (2) club-like spindles, up to $0.3 \mathrm{~mm}$ long; and (3) spindles up to $0.4 \mathrm{~mm}$ long. The polyp body wall contains (1) warty clubs, up to $0.28 \mathrm{~mm}$ long; (2) club-like spindles, up to $0.4 \mathrm{~mm}$ long; (3) capstans and ovals, up to $0.15 \mathrm{~mm}$ long; and (4) spindles up to $0.4 \mathrm{~mm}$ long. The outer layer of coenenchyme densely filled with capstans and ovals, up to $0.15 \mathrm{~mm}$ long, and may contain warty spindles up to $0.19 \mathrm{~mm}$ long.

\section{Etymology}

The specific epithet is for Simushir Island (Kurile Islands, Sea of Okhotsk), nearest to the locality where the holotype was found.

\section{Type material}

\section{Holotype}

KURILE ISLANDS: $120 \times 84 \mathrm{~mm}$, expedition of PFRC and ZIN RAS on RV “Tikhookeansky", east of Simushir Is., 46 46'41" N, 151 ${ }^{\circ} 55^{\prime} 23^{\prime \prime}$ E, 200 m, dredged, 16 Aug. 1987, S. Grebelnyi leg. (MIMB 20721).

\section{Paratype}

KURILE ISLANDS: 1 specimen, $70 \times 22 \mathrm{~mm}$, expedition of PFRC and ZINRAS on RV “Tikhookeansky", Iturup Is., V. Lukin coll., 4509'40" N, 14852'21" E, 400 m, dredged, 29 Sep. 1987 (MIMB 20703).

\section{Additional material}

three specimens were collected near Kurile Islands and stored in MIMB

KURILE ISLANDS: 1 specimen, Rikord Str., cruise of RV “Akademik Oparin”, 47²5' N, $152^{\circ} 42^{\prime}$ E, 140-166 m, dredged, 1 Jul. 1988 ( MIMB 20697); 1 specimen, Matua Is., cruise on RV “Tikhookeansky”, station 306, sample 895, 48 $01^{\prime} \mathrm{N}, 153^{\circ} 22^{\prime} \mathrm{E}, 100 \mathrm{~m}, 18$ Aug. 1987 (MIMB 20725); 1 specimen, Rasshua Is., cruise on RV “Tikhookeansky”, station 300, sample 877, 48 ${ }^{\circ} 01^{\prime} \mathrm{N}, 153^{\circ} 22^{\prime} \mathrm{E}, 100 \mathrm{~m}, 12$ Aug. 1987 (MIMB 20726).

\section{Comparative material examined}

Calcigorgia spiculifera Broch, 1935

KURILE ISLANDS: 1 specimen, $70 \times 47 \mathrm{~mm}$, expedition of PFRC and RAS on RV “Oparin", Rikord

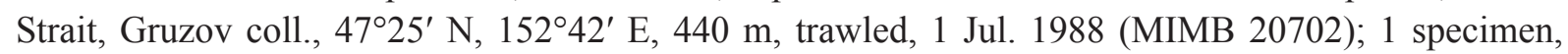
$62 \times 40 \mathrm{~mm}$, expedition of PFRC and RAS on RV “Tikhookeansky”, Urup Isl., $46^{\circ} 19.7^{\prime} \mathrm{N}, 150^{\circ} 42^{\prime}$ E, $100 \mathrm{~m}$, trawled, 1987, V. Lukin leg. (MIMB 20693).

Calcigorgia japonica Dautova, 2007

SEA OF JAPAN: 1 specimen, $39^{\circ} 35^{\prime} \mathrm{N}, 135^{\circ} 01^{\prime}$ E, 832-736 m, 8 Aug. 1933, K.M. Deryugin leg. (ZIN RAS 1/10706).

\section{Description}

Colonies irregularly branched. Holotype alcohol preserved colony, $121 \mathrm{~mm}$ high and $55 \mathrm{~mm}$ wide (Fig. 6A). Paratype $105 \mathrm{~mm}$ high and $63 \mathrm{~mm}$ wide (Fig. 6B). Polyps up to $10 \mathrm{~mm}$ high and $4 \mathrm{~mm}$ wide, disposed irregularly at distances of $2-10 \mathrm{~mm}$ from each other. Tentacles folded over polyp and partly retracted to inside; polyp body smooth and cylindrical in shape. No polyps entirely retracted into coenenchyme. 
Coenenchyme $0.8 \mathrm{~mm}$ thick and consists of two layers, a $0.6 \mathrm{~mm}$ thick outer layer, with smooth surface and a very thin inner layer. Axis made of concentric layers. Sclerites unordered in tentacles, polyp body wall and coenenchyme.

Tentacles contain clubs and spindles. Clubs mainly $0.2-0.3 \mathrm{~mm}$ long, with plump or elongated head consisting of warty processes; larger clubs up to $0.35 \mathrm{~mm}$ (Fig. 7A). Their handles straight or slightly curved, pointed or blunt, bearing small tubercles or conical processes inclined toward handle end. Clublike spindles, up to $0.26 \mathrm{~mm}$, with only slight accumulation of the processes on one end (Fig. 7B) and bearing conical hillocks, inclined toward the tips of spindle. Spindles straight or slightly curved, usually up to $0.2-0.38 \mathrm{~mm}$ long, some of these up to $0.4 \mathrm{~mm}$ (Fig. 7C-D). Some narrow spindles with tapered ends ornamented with tubercles (Fig. 7C), others with well developed conical hillocks, inclined toward tips of spindle (Fig. 7D).

In upper part of polyp body wall (about half of height of polyp's body) numerous clubs, mainly 0.15 $0.28 \mathrm{~mm}$ long, with plump head consisting of warty processes (Fig. 8A-B). Handles of short clubs mostly straight and covered with small tubercles (Fig. 8A). Longer clubs usually with slightly curved handles bearing tubercles or conical hillocks inclined to handle's end (Fig. 8B). These longer clubs transitional to club-like spindles, up to $0.4 \mathrm{~mm}$ long, bearing well-developed conical hillocks usually inclined to ends of spindle (Fig. 8F). Short clubs also coincide with ovals, mostly $0.12-0.13 \mathrm{~mm}$ long, densely covered by unordered warts (Fig. 8D), and capstans, mostly $0.12-0.15 \mathrm{~mm}$, ornamented with girdled warts or unordered processes (Fig. 8E). Longer clubs (Fig. 8B) and spindles (Fig. 8C) common here. Capstans and ovals not numerous.

In lower part of polyp body wall (about half of height), clubs mainly up to $0.15-0.28 \mathrm{~mm}$ long, not numerous (Fig. 9A-B). Handles of short clubs mostly straight and densely covered with small tubercles (Fig. 9A). Longer clubs usually with slightly curved handles bearing processes that tend to be inclined to handle's end (Fig. 9B). These longer clubs are transitional to a few club-like spindles, up to $0.3 \mathrm{~mm}$

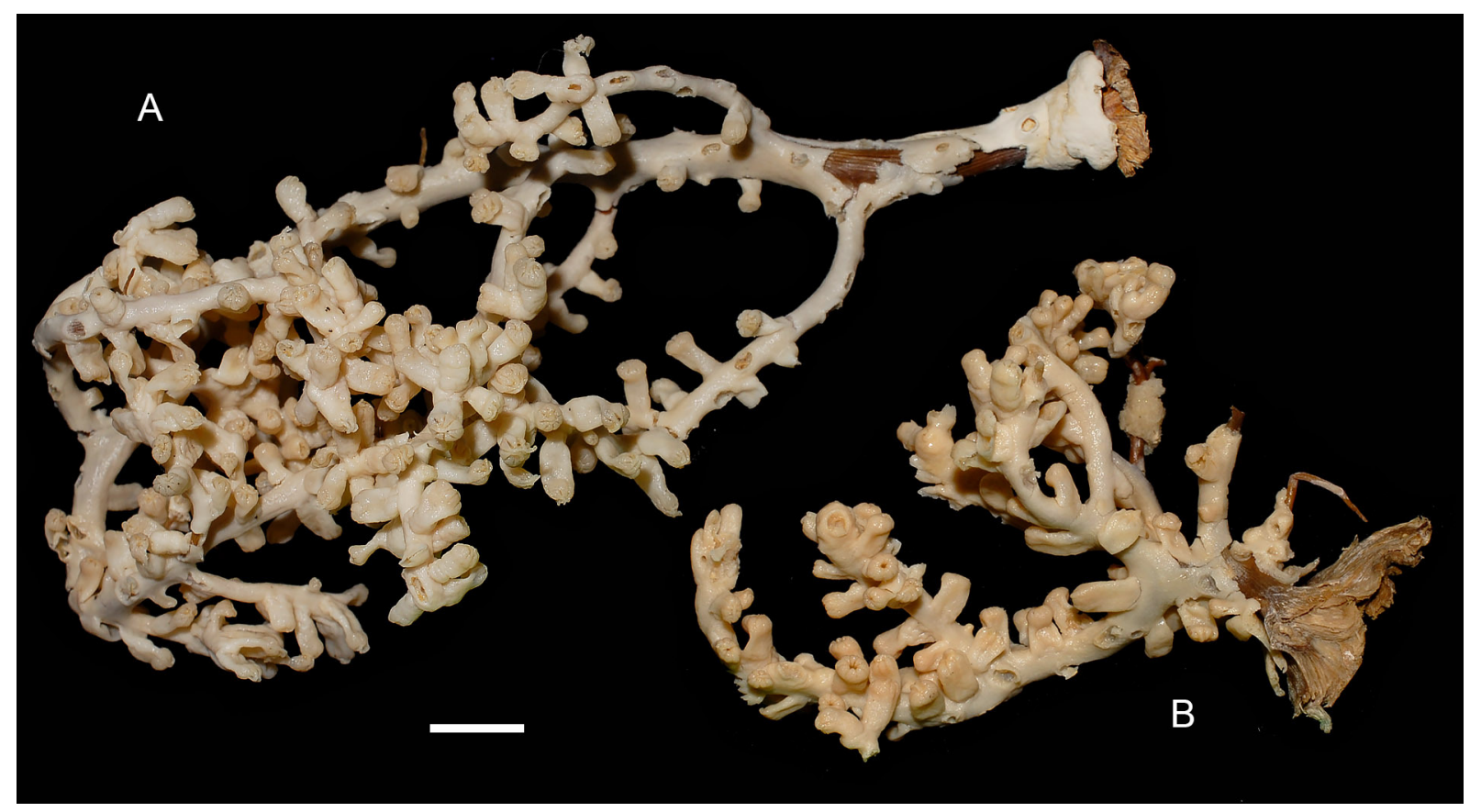

Fig. 6. Calcigorgia simushiri sp. nov. A. Holotype (MIMB 20721), Kurile Islands, Sea of Okhotsk. B. Paratype (MIMB 20703), Kurile Islands, Sea of Okhotsk. Scale bar: $10 \mathrm{~mm}$. 


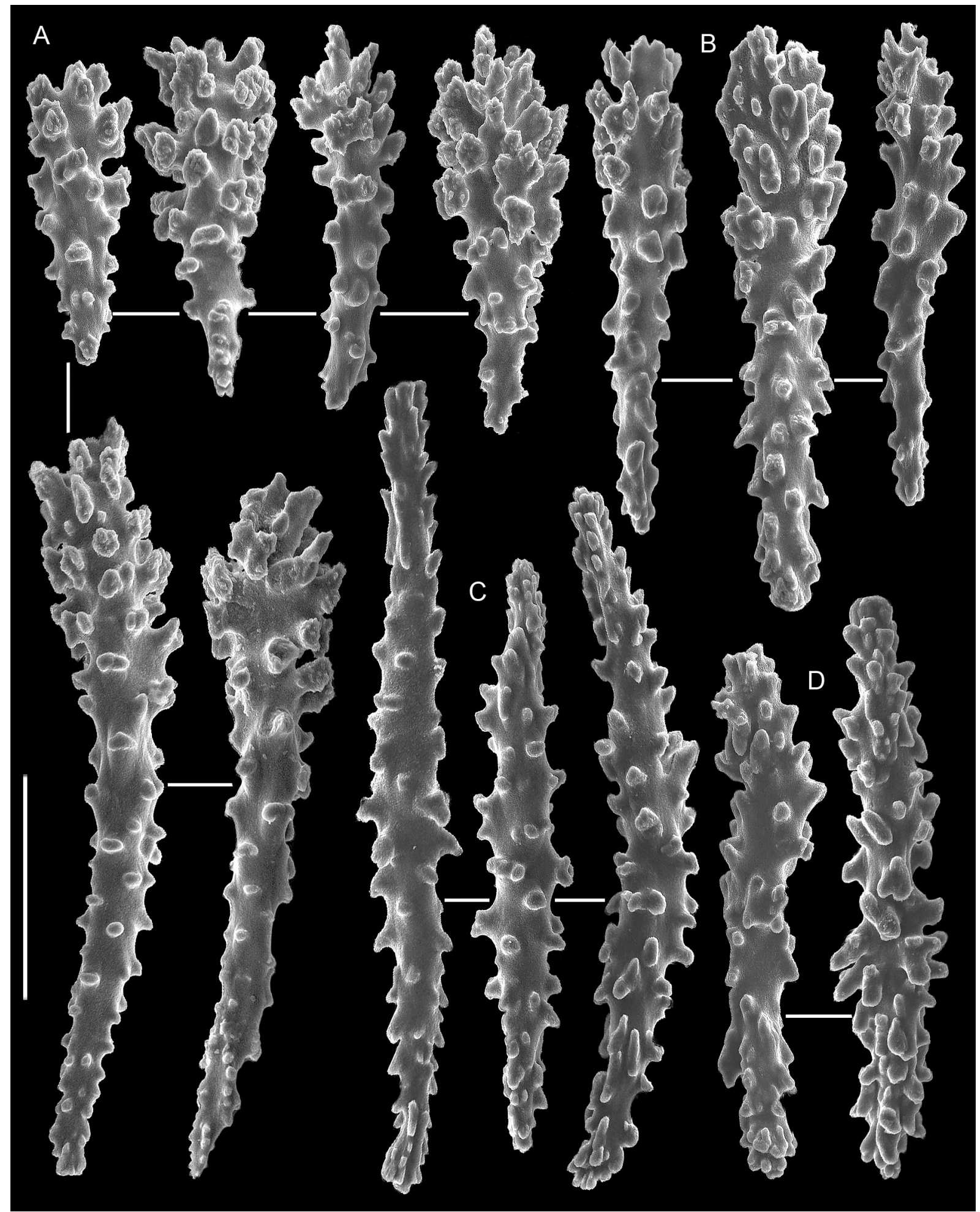

Fig. 7. Calcigorgia simushiri sp. nov., holotype (MIMB 20721), sclerites from the tentacles of polyp. A. Clubs. B. Club-like spindles. C. Spindles ornamented with tubercles. D. Spindles ornamented with conical hillocks inclined toward the spindle ends. Scale bar: $0.1 \mathrm{~mm}$. 


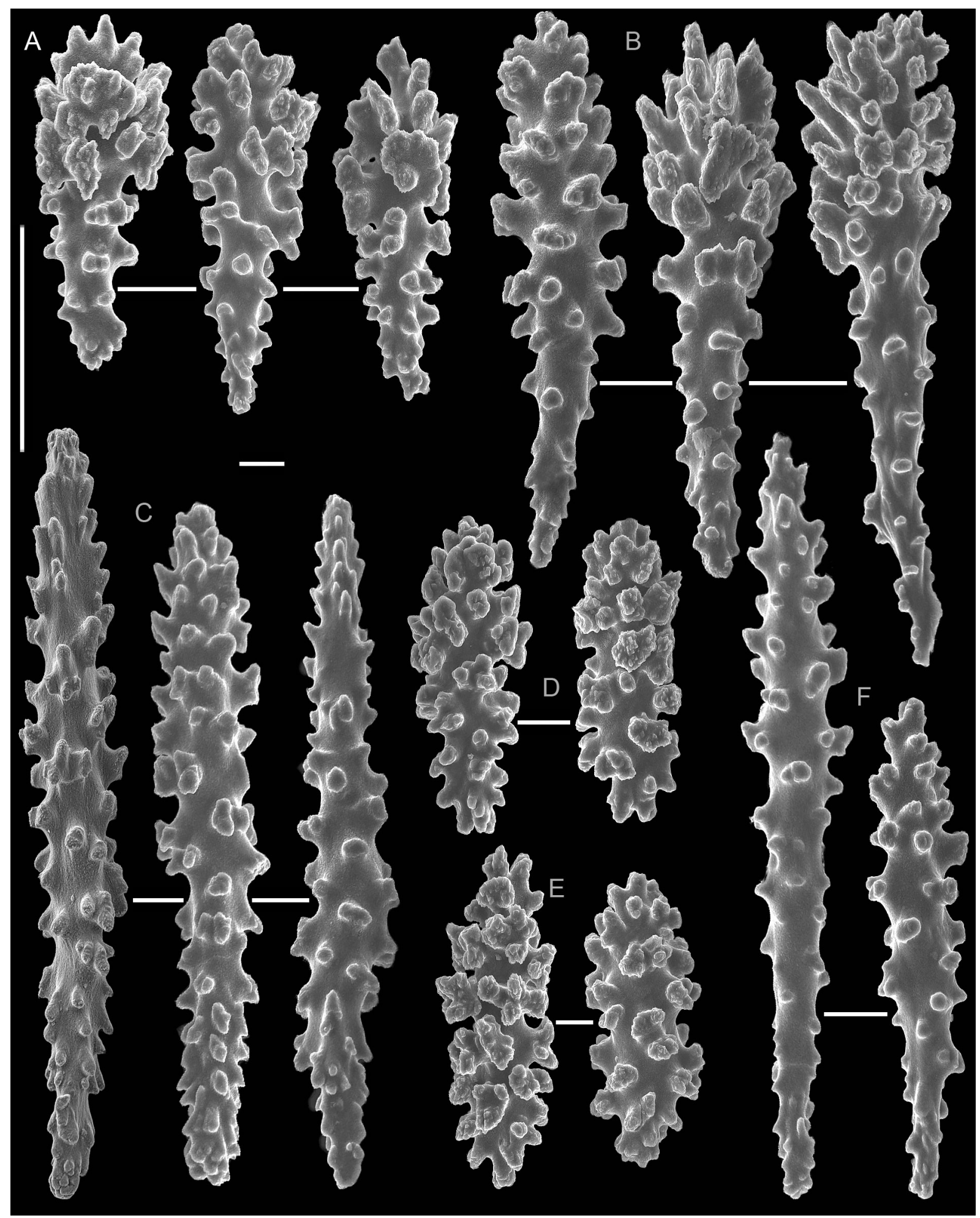

Fig. 8. Calcigorgia simushiri sp. nov., holotype (MIMB 20721), sclerites from the upper part of the body wall of polyp. A. Short warty clubs. B. Longer clubs with curved handles. C. Spindles. D. Ovals. E. Capstans ornamented with girdled warts. F. Club-like spindles. Scale bar: $0.1 \mathrm{~mm}$. 


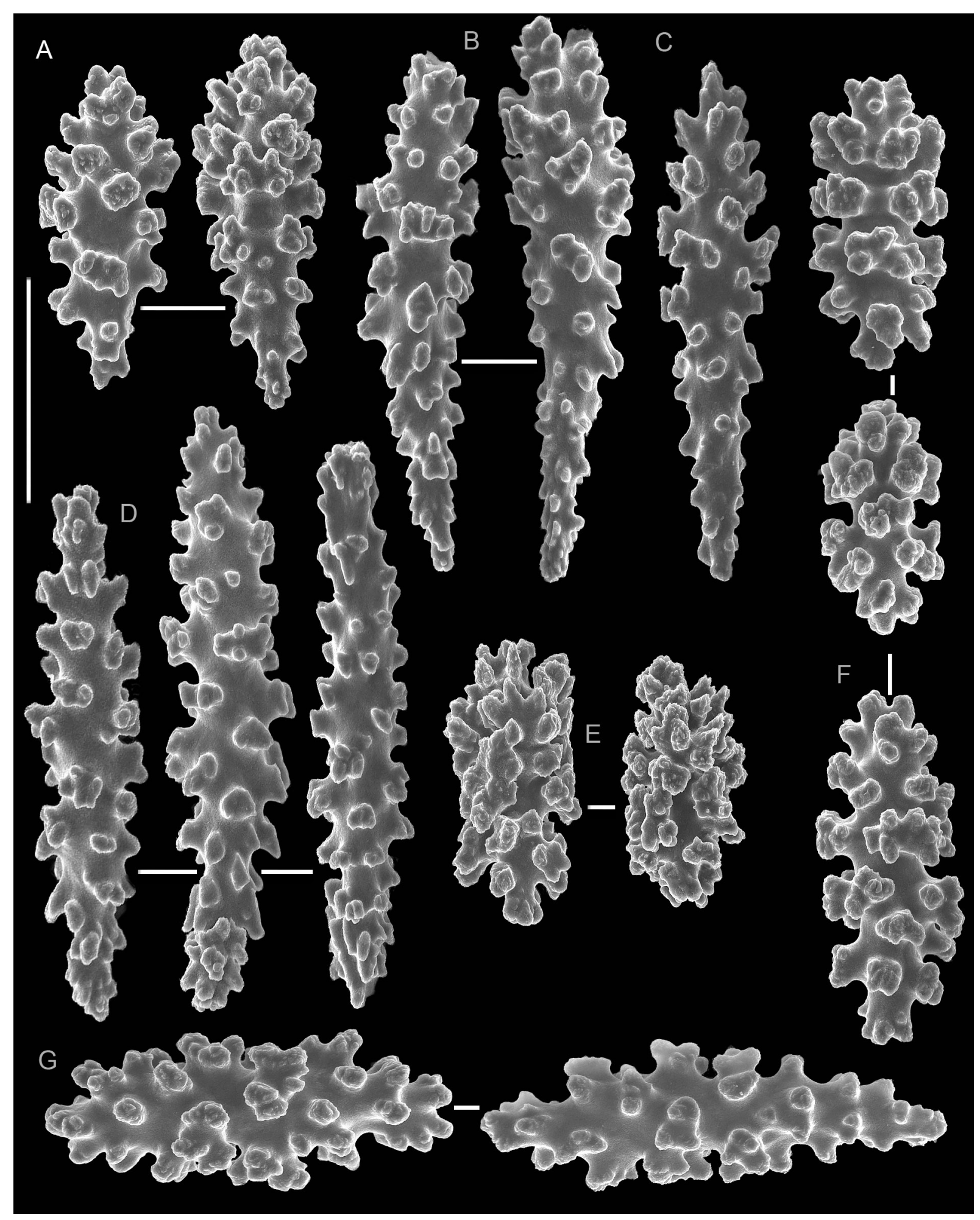

Fig. 9. Calcigorgia simushiri sp. nov., holotype (MIMB 20721), sclerites from the lower part of the polyp body wall. A. Densely ornamented short clubs. B. Longer clubs with slightly curved handles. C. Clublike spindle. D. Spindles densely ornamented with inclined conical hillocks. E. Ovals. F. Capstans ornamented with girdled warts. G. Thick spindles covered by warts tending to be girdled. Scale bar: $0.1 \mathrm{~mm}$. 
long, ornamented with small warts (Fig. 9C), and numerous spindles, mostly up to $0.25-0.3 \mathrm{~mm}$ long (Fig. 9D). Spindles bear conical hillocks, inclined toward tips of spindle. Short clubs coincide with ovals, mostly $0.11-0.12 \mathrm{~mm}$ long (Fig. 9E), and capstans, mostly $0.12-0.15 \mathrm{~mm}$ (Fig. 9F). Capstans can be assumed to be 8-radiate sclerites with well-developed plump terminal tufts. Capstans resemble thick spindles, mostly up to $0.17-0.2 \mathrm{~mm}$ long, covered by warts, which processes tend to be girdled (Fig. 9G).

External layer of coenenchyme comprises numerous ovals, mostly $0.08-0.11 \mathrm{~mm}$ long, with densely arranged warts (Fig. 10A) and capstans, mostly $0.1-0.13 \mathrm{~mm}$, with well-developed girdled warts (Fig. 10B-C). Capstans 8-radiate sclerites with two girdles of warts and plump terminal processes; some have unequally developed ends (Fig. 10B). Capstans with less calcified processes, mostly $0.13-0.15 \mathrm{~mm}$ long, also numerous (Fig. 10D). Warty spindles, mostly $0.15 \mathrm{~mm}$ long, also present here but scarce (Fig. 10E).

Internal layer of coenenchyme contains weakly calcified capstans, up to $0.13 \mathrm{~mm}$ long, of same shape as that in outer layer (Fig. 10E).

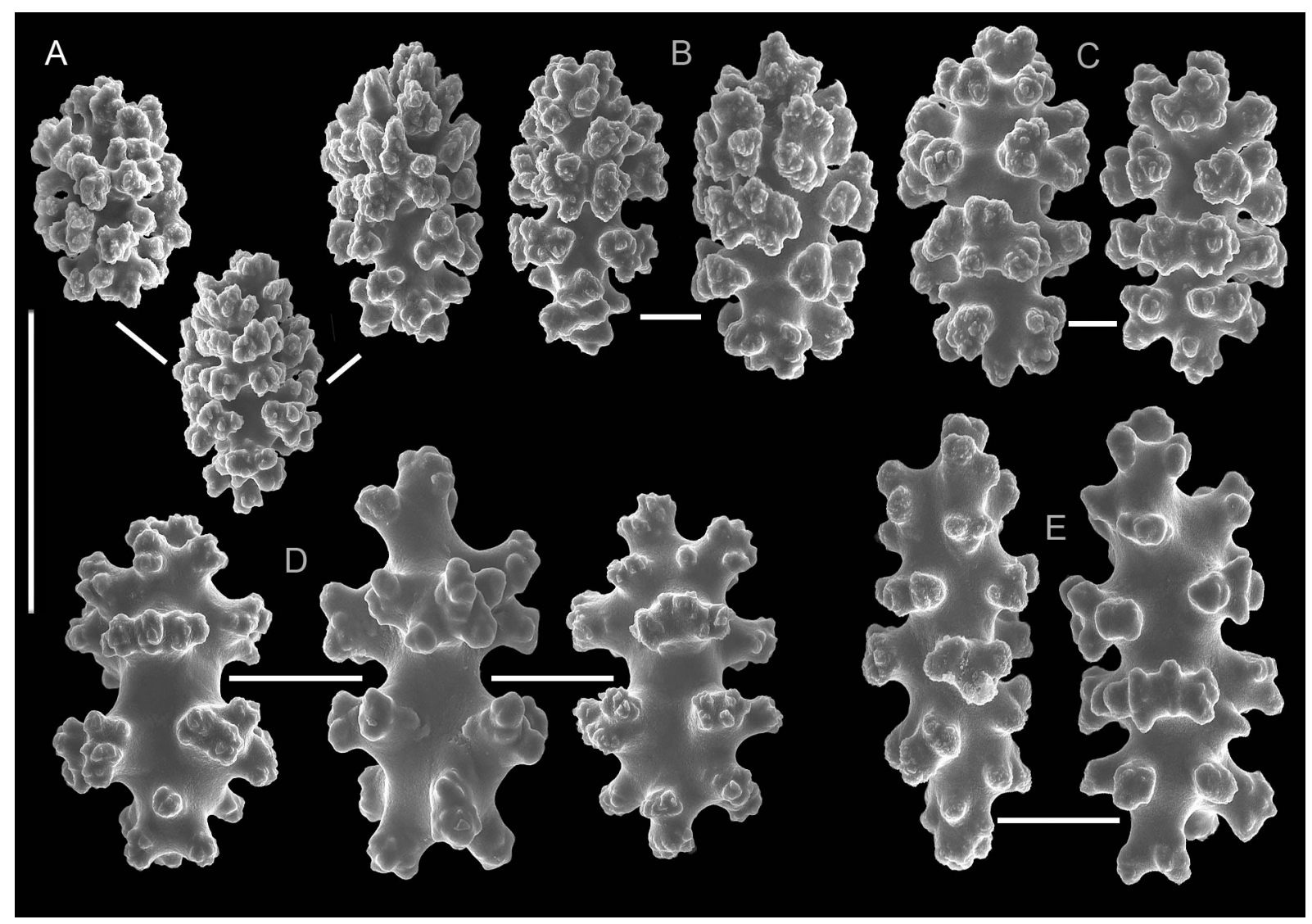

Fig. 10. Calcigorgia simushiri sp. nov., holotype (MIMB 20721), sclerites of the coenenchyme. A. Ovals. B. Capstans with unequally developed ends. C. Capstans (8-radiate sclerites) with symmetrically developed end with well calcified processes. D. Capstans (8-radiate sclerites) with less calcified processes. E. Spindles. Scale bar: $0.1 \mathrm{~mm}$. 


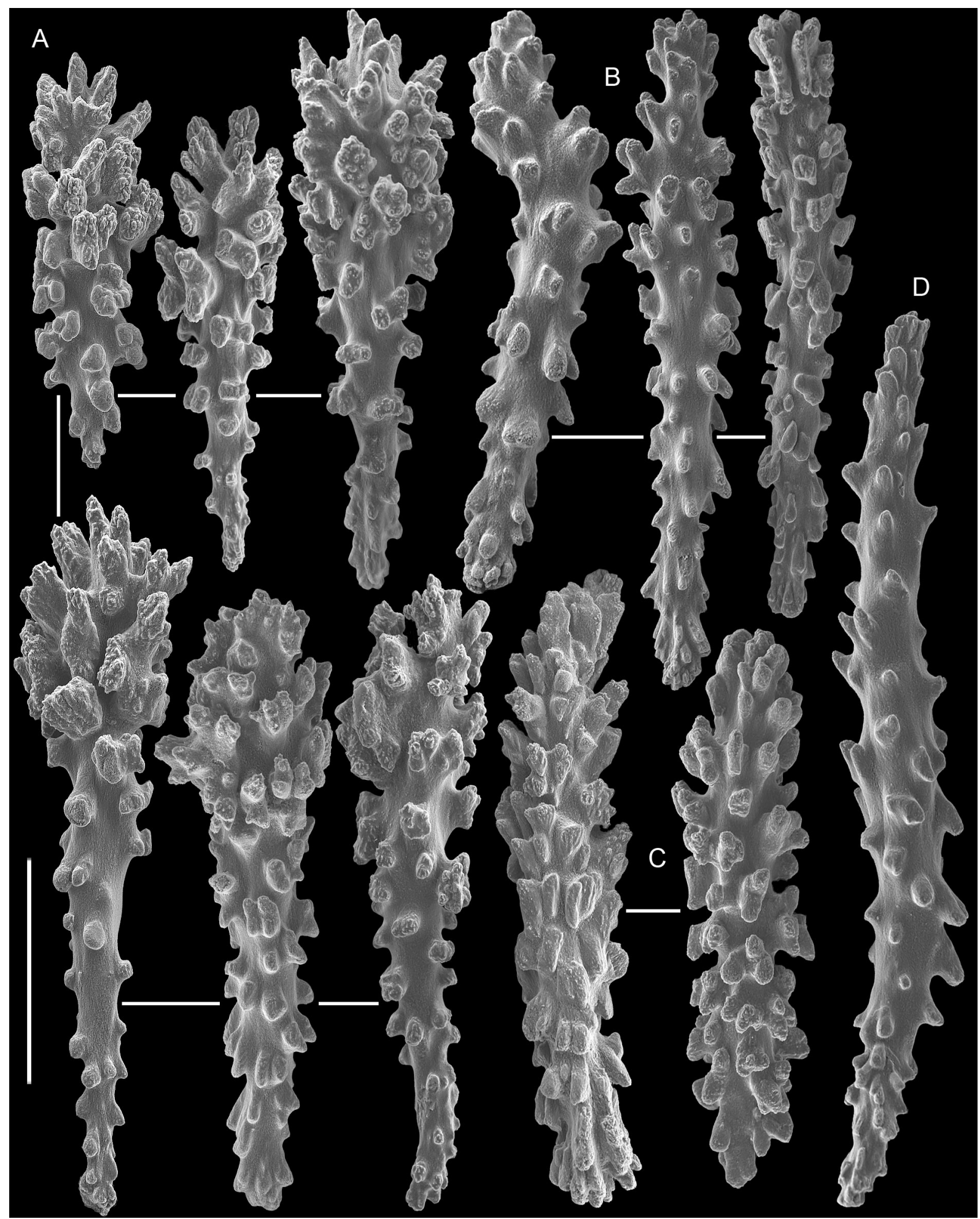

Fig. 11. Calcigorgia simushiri sp. nov., paratype (MIMB 20703), sclerites from the tentacles of polyp. A. Clubs. B. Club-like spindles. C. Spindles ornamented with conical hillocks inclined toward the spindle ends. D. Narrow tapered spindles ornamented with tubercles. Scale bar: $0.1 \mathrm{~mm}$. 


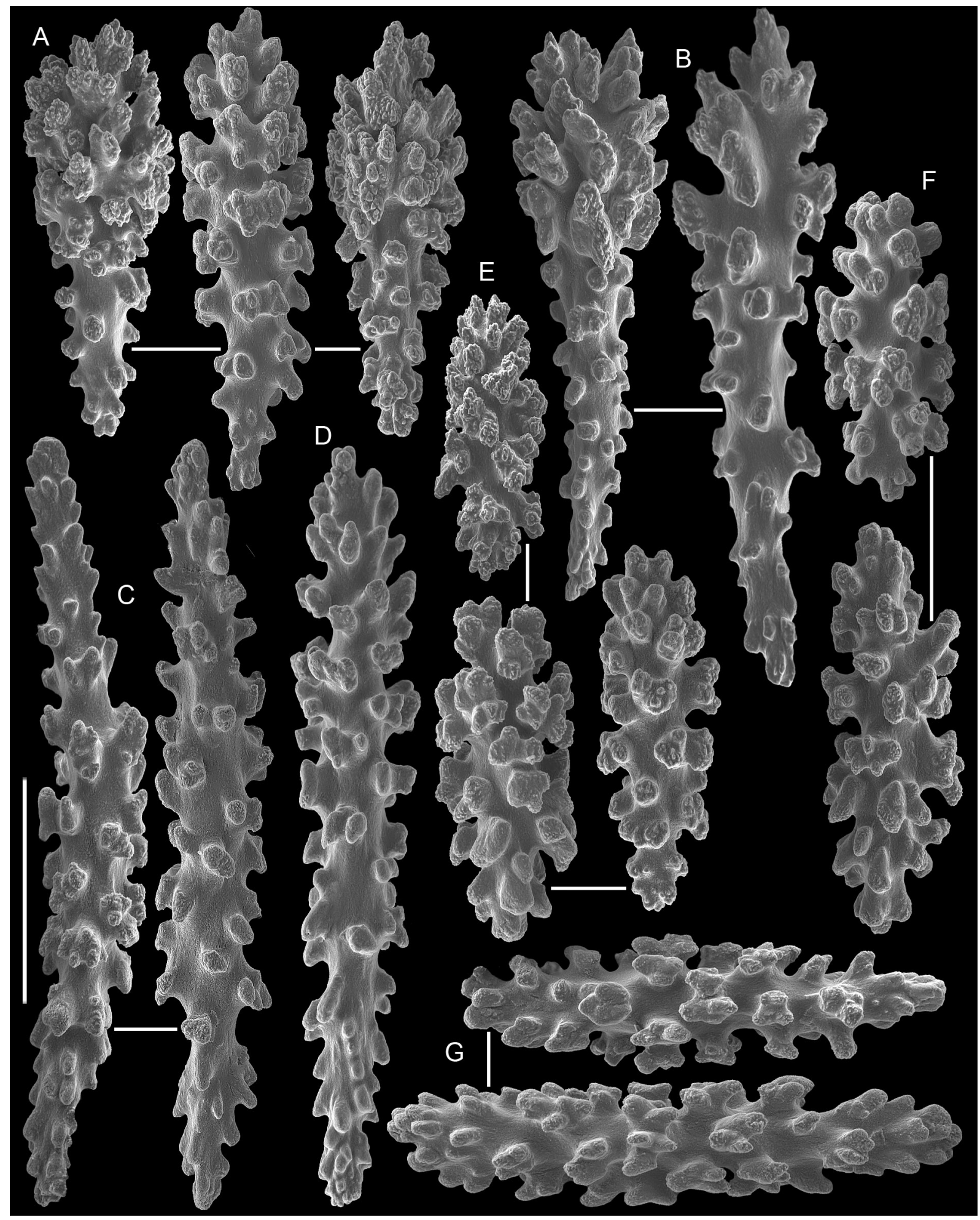

Fig. 12. Calcigorgia simushiri sp. nov., paratype (MIMB 20703), sclerites from the polyp body wall. A. Densely ornamented short clubs. B. Longer clubs with slightly curved handles. C. Tapered spindles ornamented with tubercles. D. Club-like spindle. E. Ovals. F. Capstans ornamented with girdled warts. G. Thick spindles covered by warts tending to be girdled. Scale bar: $0.1 \mathrm{~mm}$. 


\section{Paratype and variations}

Paratype MIMB 20703 has same branched colony shape (Fig. 6B). Sclerite composition in paratype (Figs 11-13) coincides with that in holotype. Sclerites in paratype are slightly larger. Clubs of tentacles (Fig. 12A) and upper part of polyp body (Fig. 13A) up to $0.35 \mathrm{~mm}$ long vs up to $0.28 \mathrm{~mm}$ in holotype (Figs 7A, 8B). Ovals in polyp body wall up to $0.15 \mathrm{~mm}$ long (Fig. 12D) vs up to $0.12 \mathrm{~mm}$ in holotype (Fig. 9E). Capstans in coenenchyme of paratype up to $0.18 \mathrm{~mm}$ long (Fig. 13B-C) vs up to $0.15 \mathrm{~mm}$ in holotype (Fig. 10C-D).

\section{Colour}

In alcohol preserved material: polyps and coenenchyme creamy, colony axis black or deeply brown, sclerites colourless.

\section{Distribution}

This species is known for certain from the Kurile Islands, Sea of Okhotsk, Northwestern Pacific. Depth range is from $140 \mathrm{~m}$ to $400 \mathrm{~m}$.

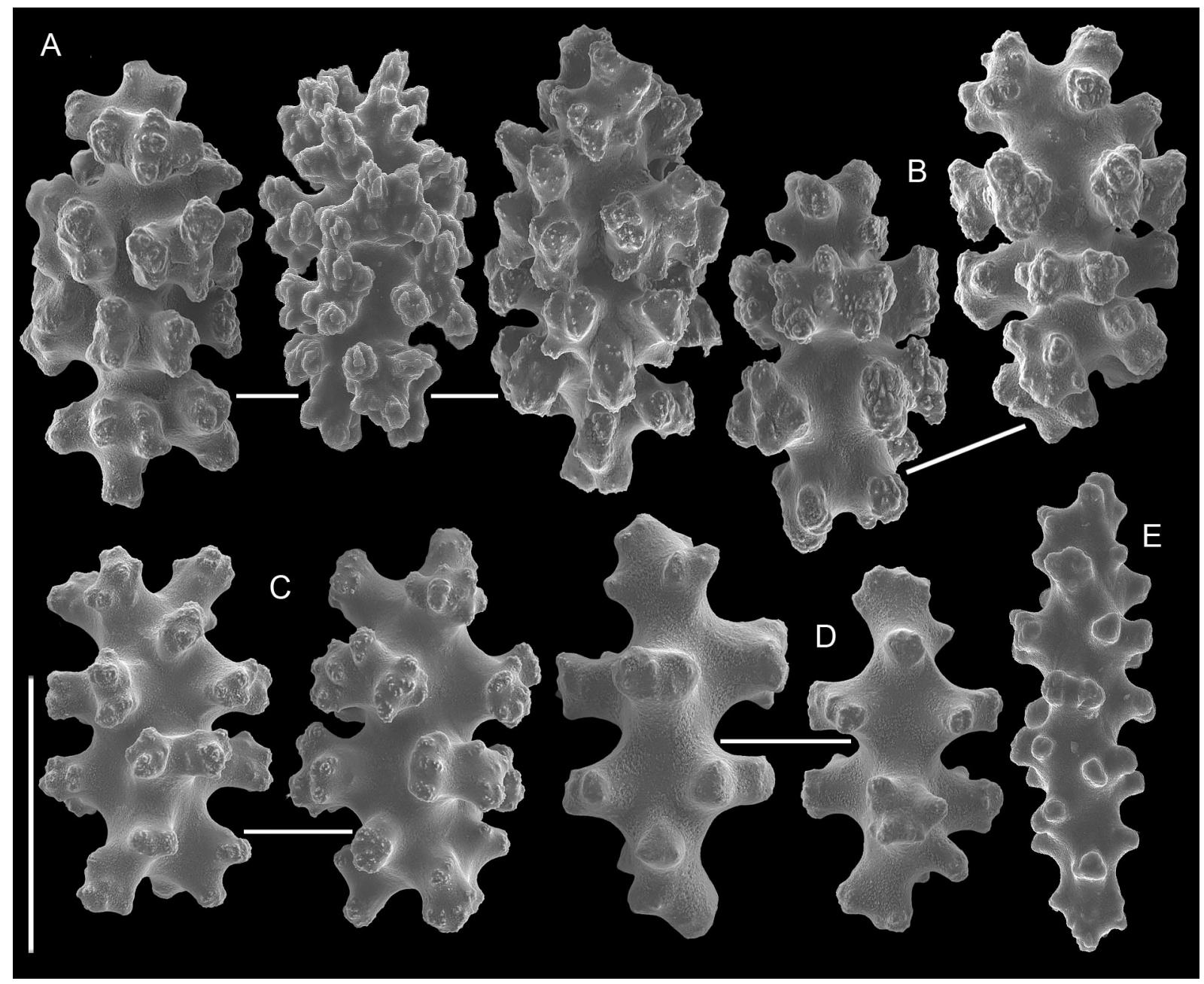

Fig. 13. Calcigorgia simushiri sp. nov., paratype (MIMB 20703), sclerites of the coenenchyme. A. Ovals. B. Capstans with unequally developed ends. C. Capstans (8-radiate sclerites) with symmetrically developed end with well calcified processes. D. Capstans (8-radiate sclerites) with less calcified processes. E. Spindles. Scale bar: $0.1 \mathrm{~mm}$. 


\section{Remarks}

This species should be identified as a member of the family Acanthogorgiidae, as it conforms well enough with the distinctive characters of the family: the polyp is not divided into an anthocodia and anthostele; tentacles, when retracted, are folded above the oral disk (Bayer 1981; Fabricius \& Alderslade 2001). Within the family Acanthogorgiidae, the examined specimen should be assigned to the genus Calcigorgia, as its distinctive characters agree with those of that genus: sclerites are small spindles, capstans and clubs that are irregularly distributed in the polyp (Bayer 1981).

The most obvious distinctive characters of $C$. simushiri sp. nov., that distinguish it from the known species of the genus, are the shape of polyp (tall body without the folded peduncle in fixed specimens) and the absence of clubs in the coenenchyme (see Table 1). Calcigorgia simushiri sp. nov. may be confused, at first glance, with C. spiculifera in terms of composition of sclerites from the polyp wall (Table 1). The size of these sclerites, however, differs significantly. Clubs in the polyp body of $C$. simushiri sp. nov. are up to $0.28 \mathrm{~mm}$ long vs up to $0.22 \mathrm{~mm}$ in C. spiculifera; spindles and club-like spindles are up to $0.4 \mathrm{~mm}$ long vs $0.25 \mathrm{~mm}$ in C. spiculifera (Table 1). Calcigorgia japonica differs from C. simushiri sp. nov. by having in the polyp body shorter sclerites and no capstans and having clubs in the coenenchyme (Table 1). Finally, C. simushiri sp. nov differs from C. matua sp. nov., in the absence of leafy clubs, which are characteristic for C. matua sp. nov. (Table 1).

\section{Discussion}

Calcigorgia differs from the other members of the family Acanthogorgiidae Gray, 1859 in having rather unordered sclerites in the polyp body wall and tentacles (Bayer 1981). This trait assures recognition of new species in the genus. However, since the description of Calcigorgia with the single species C. spiculifera was published by Broch (1935), many years passed until the second species - C. japonica Dautova, 2007 - was described from the Sea of Japan based on very limited material (Dautova 2007). A possible reason may be that the very rich region of the Sea of Okhotsk (Kurile Islands area, in particular), was beyond the scope of research on deep-water corals, and its Octocorallia fauna and their taxonomy remained poorly studied. Now, new specimens of Calcigorgia have been recognized during the processing of the collections made near the Northern Kurile Islands in the second half of the $20^{\text {th }}$ century.

The diagnoses given above will differentiate two new species from others in the genus Calcigorgia, defined in Broch (1935: 25). These data enlarge both the distribution area of the genus by adding the area of the Kurile Islands and the number of species it contains. Certainly, additional species remain to be recognized, and a key to the presently known species is, therefore, premature. As the above-described species of Calcigorgia may be difficult to distinguish in the absence of comparative material, a summary of the known species and their major characteristics is given (Table 1). From the summarized data, it is obvious that the shape of the polyp (together with its size) can contribute to distinguishing species and identifying specimens of known species. Nevertheless, the set of sclerites and their distribution in the different parts of the coral remains important for taxonomy and identification of species of Calcigorgia. Clubs of different size and shape and their distribution in the coral seem to be most useful characters for distinguishing species of Calcigorgia, whereas straight spindles and club-like spindles differ only in their length (Table 1). The ovals, such as depicted in Figs 3F, 4F and 8E, should be used with caution for taxonomy in the genus because these could be derived from the capstans due to the very intense calcification process in the coral.

Formulating the diagnosis of Calcigorgia, Broch (1935: 25) described the sclerites set as follows: "Die Spicula sind kurze und derbe, stark bewarzte Stäbe and Keulen". However, the first of the species described above, C. matua, sp. nov., contains both warty clubs and clubs with leafy processes on their 
DAUTOVA T.N., Two new species of Calcigorgia gorgonians from the Kurile Islands

heads, the first leafy clubs documented in Calcigorgia. This led to the modification of the diagnosis of the genus as proposed above (see "Results").

Thus, the genus Calcigorgia has proven to be more speciose than known before and additional work remains to be done on the genus, especially in the Sea of Okhotsk and around the Kurile Islands.

The geographic ranges of species of Calcigorgia remain to be updated and determined. In general terms, the range of each species is restricted, although the type species, C. spiculifera, has a relatively wide range from Alaska and the Aleutian Islands to Sakhalin Island and the Kurile Islands (Broch 1935; Heifetz et al. 2005; Dautova 2007, 2008, 2011). This type species should not be redescribed (and a neotype not be designated) as its first description (Broch 1935: 22-25, figs 13-14) is quite detailed and well-illustrated possessing enough information for the identification of the newly collected specimens. However, the relatively wide range of $C$. spiculifera may require a study of its intra-species variability for better understanding of the species characters and its pathways of dispersal in the northern Pacific.

\section{Acknowledgements}

The author thanks Dr Sergey Grebelnyi and the staff of the Research Vessels "Akademik Oparin", "Tikhookeansky" and "Odyssey" for their valuable contribution to the finding of these species. The author greatly appreciates the reviewers' careful reading of the manuscript and helpful comments. This work was partly sponsored by the Asia-Pacific Network for the Global Change Research (APN) grant CAF2016-RR08-CMY-Dautova.

\section{References}

Bayer F.M. 1981. Key to the genera of Octocorallia exclusive of Pennatulacea (Coelenterata: Anthozoa), with diagnoses of new taxa. Proceedings of the Biological Society of Washington 94: 901-947.

Bayer F.M., Grasshoff M. \&Verseveldt J. 1983. Illustrated Trilingual Glossary of Morphological and Anatomical Terms Applied to Octocorallia. E.J. Brill/W. Backhuys, Leiden.

Broch H. 1935. Oktokorallen des nördlichsten Pazifischen Ozeans und ihre Beziehungen zur atlantischen Fauna. Avhandlinger utgitt av det Norske Videnskaps-Akademi i Oslo. I. Matematisk-Naturvidenskapelig Klasse 1: 1-35.

Cairns S.D. \& Bayer F.M. 2005. A review of the genus Primnoa (Octocorallia: Gorgonacea: Primnoidae), with the description of two new species. Bulletin of Marine Science 77: 225-256.

Dautova T.N. 2007. Gorgonians (Anthozoa: Octocorallia) of the Northwestern Sea of Japan. Russian Journal of Marine Biology 33: 297-304.

Dautova T.N. 2008. Distributional patterns of the octocorals in the Indo-West Pacific and the species identification problem: what taxa could be the indicators? In: Lutaenko K.L. (ed.) Marine Biodiversity and Bioresources of the North-Eastern Asia. Proceedings of the International APN Conference, 21-22 October, Cheju, Korea: 24-33.

Dautova T.N. 2011. Pathways for dispersal of the octocorals in the East Asia seas - inter-faunal connectivity and centers of biodiversity. Bulletin of the Far East Branch of the Russian Academy of sciences 158: 31-39. [In Russian with English abstract.]

Fabricius K.K. \& Alderslade P.P. 2001. Soft Corals and Sea Fans: a Comprehensive Guide to the Tropical Shallow Water Genera of the Central-West Pacific, the Indian Ocean and the Red Sea. Australian Institute of Marine Science, Townsville, Australia.

Heifetz J. 2002. Coral in Alaska: distribution, abundance, and species associations. Hydrobiologia 471: 19-28. https://doi.org/10.1023/A:1016528631593 
Heifetz J., Wing B.L., Stone R.P., Malecha P.W. \& Courtney D.L. 2005. Corals of the Aleutian Islands. Fisheries Oceanography 14: 131-138. https://doi.org/10.1111/j.1365-2419.2005.00371.x

Manuscript received: 20 February 2017

Manuscript accepted: 24 August 2017

Published on: 26 February 2018

Topic editor: Rudy Jocqué

Desk editor: Kristiaan Hoedemakers

Printed versions of all papers are also deposited in the libraries of the institutes that are members of the EJT consortium: Muséum national d'Histoire naturelle, Paris, France; Botanic Garden Meise, Belgium; Royal Museum for Central Africa, Tervuren, Belgium; Natural History Museum, London, United Kingdom; Royal Belgian Institute of Natural Sciences, Brussels, Belgium; Natural History Museum of Denmark, Copenhagen, Denmark; Naturalis Biodiversity Center, Leiden, the Netherlands; Museo Nacional de Ciencias Naturales-CSIC, Madrid, Spain; Real Jardín Botánico de Madrid CSIC, Spain. 